\title{
PEMANFAATAN KOTORAN SAPI SEBAGAI SUMBER ENERGI BIOGAS DI KABUPATEN TELUK BINTUNI PROVINSI PAPUA BARAT
}

\author{
Budi Santoso*, Irba U. Warsono, Daniel Y. Seseray, Purwaningsih \\ Jurusan Peternakan, Fakultas Peternakan, Universitas Papua, Manokwari, Indonesia \\ *Penulis Korespondensi: b.santoso@unipa.ac.id
}

\begin{abstract}
Abstrak
Tujuan kegiatan pengabdian pada masyarakat ini adalah untuk memperkenalkan teknologi biogas kepada peternak sapi dalam rangka penyediaan sumber energi alternatif yang ramah lingkungan. Kegiatan ini dilaksanakan Distrik Manimeri, Ka bupaten Teluk Bintuni, Provinsi Pa pua Barat. Pelatihan ini dilakukan dalam beberapa tahap yaitu sosialisasi tentang teknologi biogas, pemasangan biod igester portabel dan pembuatan biodigester sederhana, pengisian biodigester, uji pembakaran biogas, dan monitoring dan evaluasi. Hasil kegiatan ini menunjukkan bahwa peserta kegiatan mempunyai respon yang baik terhadap materi yang disampaikan. Setelah 3 minggu pengisian feses sapi ke dalam biodigester, biogas telah terbentuk dan dapat menyalakan kompor terus menerus. Direkomendasikan bahwa biodigester sederhana dapat diterapkan pada petani yang memelihara sapi pada skala 3-5 ekor dalam rangka penyediaan sumber energi alternatif y ang ra mah lingkungan.
\end{abstract}

Kata kunci: Biodigester; Biogas;Feses Sapi; Energi; Pengabdian Pada Masyarakat.

\begin{abstract}
The purpose of the community service activity was to introduce biogas technologyto cattle farmers in order to provide alternative energy sources that are environmentally friendly. This activity was carried out at Manimeri District, Teluk Bintuni Regency, West Papua Province. The training was carried out in several stages, namely socialization of biogas technology, installation of portable biodigester, making simple biodigester, filling of biodigester, biogas combustion testing and evaluation monitoring. The results of the activities showed that the participants of the activity have a good response to the material provided. After 3 weeks offilling cattlefeces into biodigester, biogas has beenformed and can ignite the stove continuously. It was recommended that simple biodigester can be applied to farmers who raising a scale of $3-5$ head of cattle in the context of providing alternative energy sources that are environmentallyfriendly.
\end{abstract}

Keywords: Biodigester; Biogas; Cattle Feces; Energy; Community Service.

\section{PENDAHULUAN}

Bioga s a tau gas bio merupakan gas y ang dihasilkan oleh aktivitas mikroorganisme anaerobik atau fermentasi dari bahan-bahan organik, seperti kotoran manusia dan hewan, limbah domestik atau rumah tangga, sampah orga nik y ang mudah diurai (biodegradable) (Wahyuni, 2013). Menurut Al Seadi et al. (2013), serangkaian proses yang terjadi pada pembentukan biogas meliputi hidrolisis, asidogenesis, asetogenesis, dan metanogenesis. Biogas merupakan bahan bakar alternatif masa depan karena dapat digunakan sebagai bahan bakar kendaraan maupun untuk menghasilkan listrik termasuk untuk memenuhi kebutuhan energi rumahtangga.

Pemanfaatan limbah pertanian dan peternakan sebagai sumber energibiogas memegang peranan yang penting dalam bidang lingkungan, karena biogas yang mengandung gas metana $\left(\mathrm{CH}_{4}\right)$ merupakan salah satu dari kelompok Gas Rumah Kaca (GRK) yang lebih berbahaya dalam pemanasan global bila dibandingkan dengan gas karbondioksida $\left(\mathrm{CO}_{2}\right)$. Hal ini dikarenakan karbon yang menyusun biogas merupakan karbon yang diambil dari atmosfer oleh fotosintesis tanaman, sehingga bilamana dilepaskan la gi ke atmosfer lagi tidak akan menambah jumlah karbon di atmosfer apabila dibandingkan dengan pembakaran bahan bakar fosil. Penggunaan biogas mampu mengurangi emisi gas rumah kaca sebagai akibat dari pengurangan penggunaan energifosil.

Prospek pengembangan teknologi biogas ini sangat besar terutama di daerah pedesaan yang sebagian besar masyarakatnya bekerja disektor peternakan dan perta nian. Pada umumnya masyarakat yang berprofesi sebagai petani peternak mempunyai ternak seperti unggas, kambing, sapi, kerbau, dan lain-lain. Pemanfaatan limbah peternakan (kotoran temak) sebagai biogas merupakan salah satu alternatif yang tepat untuk mengatasi kelangkaan bahan bakar minyak 
di daerah pedesaan karena dapat menyediakan sumber energi untuk keperluan sehari-hari dalam rumah tangga peta ni peternak.

Populasi ternak besar, terutama sapi di Kabupaten Teluk Bintuni cukup tinggi yaitu 2.383 ekor yang terkonsentrasi di tiga distrik yaitu Distrik Sumuri 660 ekor, Distrik Bintuni 654 ekor dan Distrik Manimeri 743 ekor (BPS, 2017). Menurut Karno dan Koesmantoro (2013), setiap ekor ternak sapi atau kerbau dapat menghasilkan $10 \mathrm{~kg}$ kotoran atau feses yang setara dengan $\pm 2 \mathrm{~m}^{3}$ bioga s per siklus (20-21 hari). Dari segi perhitungan ekonomis bahwa setiap $1 \mathrm{~m}^{3}$ biogas dapat diseta rakan dengan 0,62 liter minyak tanah. Selain itu limbah biogas yang berupa lumpur dari efluent atau outlet digester biogas yang berwujud cairan ini merupakan Pupuk Organik Cair (POC) yang sangat ka ya akan unsur-unsur yang dibutuhkan oleh tanaman. Lumpur dari outlet sebagai limbah biogas juga dapat diubah da lam bentuk butiran a tau gra nul dengan cara dikeringkan juga memiliki nilai ekonomi bila dijual seba gai Pupuk Orga nik Granul(POG).

Berda sarkan potensi sapi dan kotoran temak yang ada tersebut maka perlu dilakukan kegiatan pelatihan pemanfaatan kotoran ternak sebagai sumber energi biogas di Distrik Ma nimeri, Kabupaten Teluk Bintuni.

\section{METODE PELAKSANAAN KEGIATAN 2.1 Waktu dan Tempat}

Kegiatan pelatihan ini dilakukan selama 2 bulan yaitu bulan Agu stus - September 2019 di Satuan Pemukiman I, Distrik Manimeri, Kabupaten Teluk Bintuni Provinsi Pa pua Barat. Kegiatan inidiikuti oleh 30 orang peserta yang berasal dari perwakilan peternak sapi dan petugas penyuluh di lingkungan Dinas Pertanian Kabupaten Teluk Bintuni. Kegiatan yang dilaksanakan meliputi sosialisasi tentang teknologi biogas, pemasangan biodigester portabel dan pembuatan biodigester sederhana, pengisian biodigester, uji pembakaran biogas, dan monitoring dan evaluasi. Ma teri sosialisasi diberikan dengan metode ceramah menggunakan alat bantu infocus. Disa mping itu setiap peserta dibagikan materi da lam bentuk modul.

\subsection{Sosialisasi Teknologi Biogas}

Kegiatan sosialisa si dilaksanakan di Laboratorium dan Puskeswan Dinas Pertanian Kabupaten Teluk Bintuni, Distrik Manimeri, Kabupaten Teluk Bintuni. Peserta kegiatan adalah petugas penyuluh dan perwakilan peternakan sapi. Tujuan kegiatan ini adalah untuk memberikan pengetahuan kepada peternak tentang proses pembentukan biogas, manfaat biogas, cara pembuatan biodigester sederhana dan cara pengoperasiannya. Sosialisasi dilakukan dengan metode ceramah menggunakan alat bantu infocus dan setiap peserta diberikan modul. Setelah ceramah dila njutkan tanya jawab antara peserta dengan pemateri.

\subsection{Pemasangan Biodigester Portabel}

Biodigester portabel yang dira kit terbuat dari bahan flat PVC $8 \mathrm{~mm}$, kerangka besi siku $4 \mathrm{~cm}$ tebal 2,3 mm dengan kapasitas $1 \mathrm{~m}^{3}$. Biodigester ini dilengkapi dengan penampung gas yang terbuat dari plastik, regulator, panel blower dan kompor biogas. Pemasangan biodigester portabel di Laboratorium dan Puskeswan Dinas Pertanian Kabupaten Teluk Bintuni, Distrik Manimeri Kabupaten Teluk Bintuni sesuai manual yang tersedia (Gambar 1).
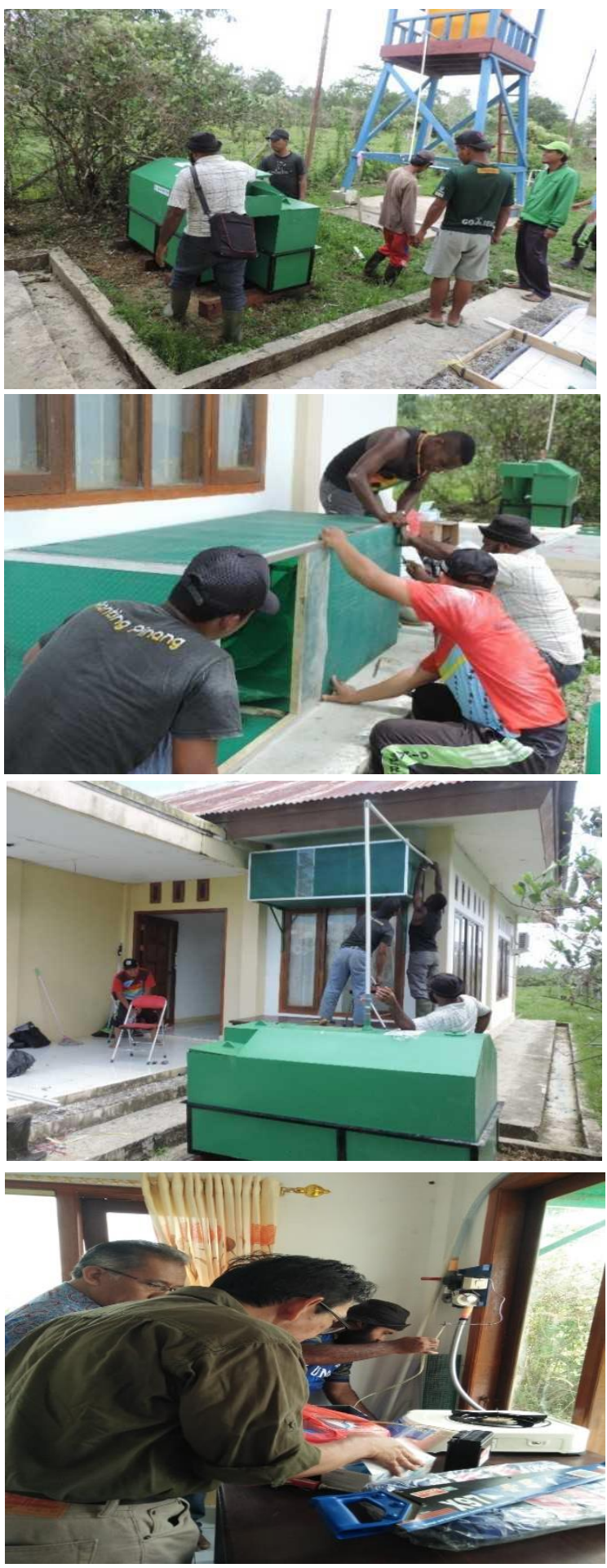

Gambar 1. Pemasangan biodigester portabel dan aksesorisnya.

\subsection{Pembuatan Biodigester Sederhana}

Biodigester sederhana dibuat dari bahan-bahan yang dijualdi toko bangunan seperti plastik PVC, terpal, pipa 
PVC, selang plastik sehingga mudah diperoleh oleh peternak. Proses pembuatan biodigester sederhana berkapasitas $4 \mathrm{~m}^{3}$, tertera pada Gambar 2 .
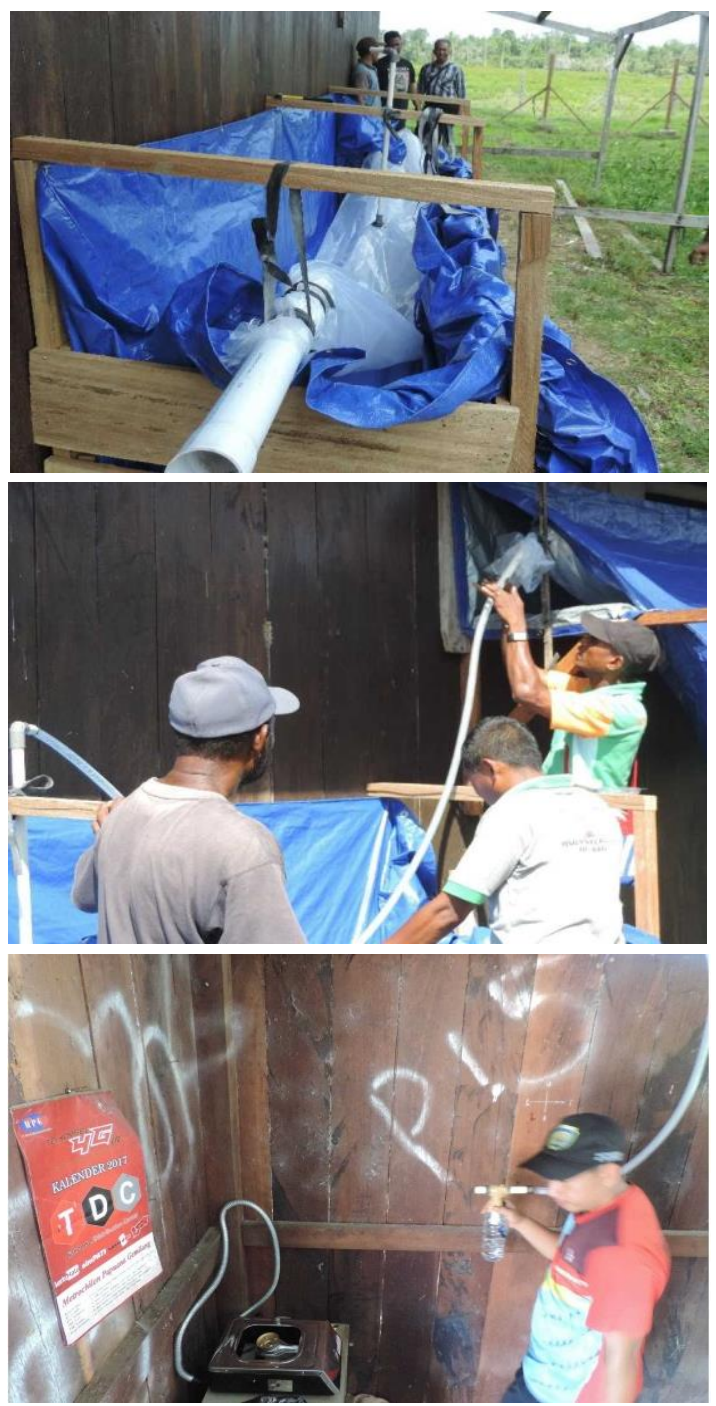

Gambar 2. Pembuatan biodigester sederhana.

\subsection{Proses Pengisian dan Pengoperasian Biodigester} Pengoperasian biodigester dia wali dengan pembuatan adonan kotoran ternak sebagai starter. Kotoran/feses sapi dimasukkan ke dalam suatu ember yang cukup besar kemudian diencerkan dengan air (dengan perbandingan 50-60\% kotoran sapi dan 40-50\% air) atau $1: 1$ serta tambahkan sedikit larutan gula kemudian aduk sa mpai merata (Ga mbar 3).

Proses pengisian adonan starter tersebut diulangi sehingga tinggi permukaan starter menutupi ujung bawah pipa input (sekitar 1/3 dari total volume biodigester).

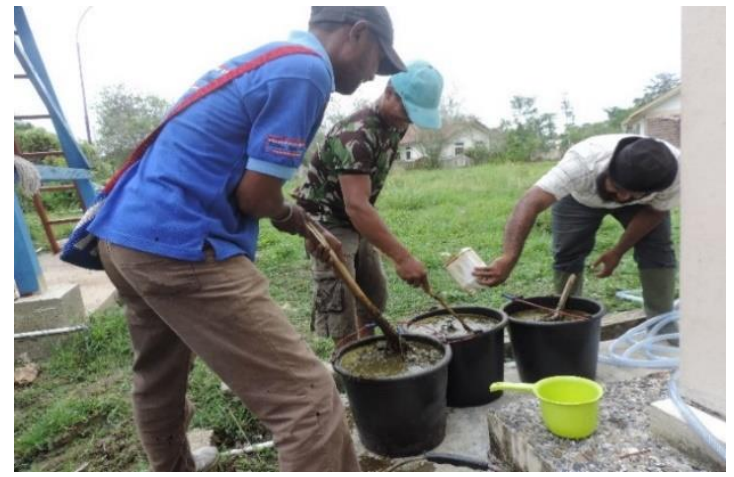

Gambar 3. Pembuatan a donan feses sapi da n air $(1: 1)$

Air dimasukkan ke dalam lubang pipa output hingga ketinggiannya mencapai ujung bawah pipa output. Apabila adonan kotoran ternak tersebut sudah cukup mencapai permukaan ujung ba wah pipa output maka tidak perlu ditambahkan air lagi.

Setelah lubang input dan output biodigester tertutup air maka kondisi di dalam digester menjadi anaerob (kedap udara) sehingga bakteri anaerob menjadi aktif dan berkembangbiak ditandai dengan mengembangnya plastik penampung biogas dalamjangka waktu sekitar 3 minggu. Proses terbentuknya biogas juga bergantung pada temperatur lingkungan internalnya di sekitar biodigester.

\subsection{Pengujian Kompor Biogas, Monitoring dan Evaluasi}

Pengujian kompor biogas dilaksanakan 3 minggu setelah pengisian kotoran ternak di dalam biodigester. Panel blower disambung ke sumber listrik/accu motor kemudian dinyalakan sehingga aliran biogas menuju kompor menjadi lebih kuat. Kran gas yang terdapat di kompor dibuka kemudian disulut menggunakan pemantik api/korek api di a tas burner kompor sehingga komporbiogas menyala.

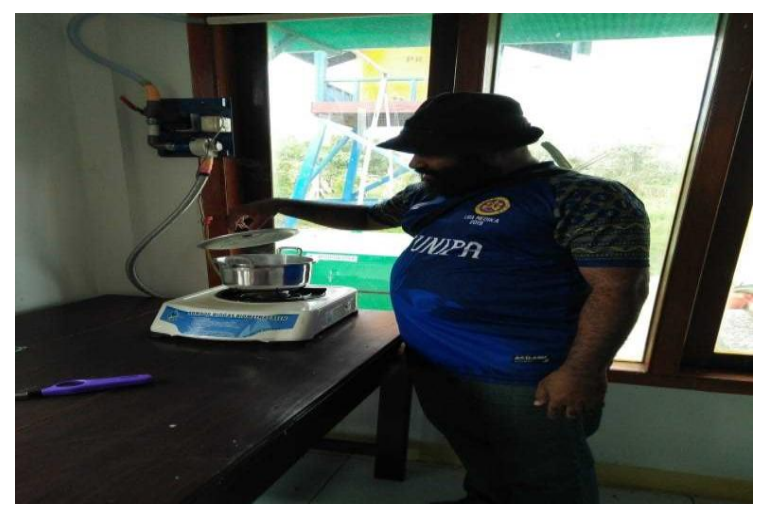

Gambar 4. Pengujian kompor biogas untuk memasak air.

Monitoring dan evaluasi merupakan kegiatan untuk menilai tingk at keberhasilan dan keberla jutan kegiatan pengabdian ini. Kegiatan monitoring dilakukan bersamaan pengujian kompos biogas dilanjutkan 1 bulan setelah monitoring pertama untuk memastikan 
biodigester masih diisi kotoran ternak secara rutin sehingga biogas dihasilkan secara kontinyu.

\section{HASIL DAN PEMBAHASAN \\ 3.1 Kegiatan Sosialisasi}

Kegiatan sosialisasi diikuti 30 peserta terdini atas peternak sapi dan petugas penyuluh Dinas Pertanian Kabupaten Teluk Bintuni. Sosialisasi dila kukan dengan metode ceramah dengan menggunakan alat bantu infocus. Disamping itu masing-masing peserta diberikan materi berupa modul. Materi yang disampaikan meliputi manfaat pembuatan bioga s dari bahan kotoran ternak, cara pembuatan biodigester sederhana, cara pengoperasian dan perawatan biodigester, Pada bagian akhir sosialisasi, peserta diberikan kesempatan untuk bertanya dan diskusi dengan narasumber. Peserta sosialisasi sangat serius dan antusias dengan materi yang disampaikan, hal ini diindika sikan dari ba nyaknya peserta y ang mengajukan pertanyaan.

Pengetahuan peternak yang masih terbatas perlu ditingka tkan mela lui tra nsfer dan a plikasi ilmu dibidang peternakan. Teknologi biogas merupakan salah satu teknologi pengolahan limbah peternakan. Penerapan teknologi bioga s memberikan beberapa manfaat, antara lain: 1) mengurangi pencemaran lingkungan akibat kotoran ternak y ang menumpuk; 2) dapat dimanfaatkan sebagai bahan bakar alternatif; 3) mengurangi pengeluaran rumah tangga untuk pembelian bahan bakar; 4) ha sil sa mping biogas dapat

diolah menjadipupuk organik (cair dan padat).

\subsection{Pengisian dan Pemeliharaan Digester}

Pengisian campuran kotoran sapi dan air (1 : 1) dilakukan oleh peserta pelatihan secara bersama-sama pada saat pelatihan. Selanjutnya untuk menjamin ketersediaan bahan organik yang akan difermentasi menjadi biogas, maka peserta pelatihan secara bergiliran melakukan pengisian digester setiap 3 hari. Apa bila digester diisi dengan kotoran temak atau bahan organik lain yang mudah terurai secara rutin maka bioga s yang dihasilkan akan tetap stabil.

Beberapa hal perlu diperhatikan dalam pemeliharaan biodigester dan peralatannya sebagai berikut:

a. Tidak meletakkan benda berat di atas biodigester.

b. Tidak memasukkan selain sampah organik ke dalam biodigester.

c. Tidak melakukan pengisian melebihi kapasitas biodigester.

d. Burner kompor biogas harus dibersihkan secara berka la dari kerak yang dapat menyumbat a liran biogas

e. Panel blower set dikontrol untuk menghindari disfungsi terutama pada blower.

Digester portabely ang digunakan pada kegiatan terbuat da ri ba han flat PVC dengan kerangka besi siku sehingga harganya relatif mahal. Disamping itu, digester ini dikirim dari luar Papua sehingga membutuhkan biaya pengiriman. Menurut Herriyanti (2015) keuntungan penggunaan digester fiber glass yaitu mudah dideteksi bila ada kebocoran, daya tahan kuat, dan dapat dipindahkan. Sebaliknya digester sederhana terbuat a ntara la in dari pipa PVC, terpal dan kerangka papan dan kayu balok, sehingga biaya pembuatannya murah dan perala tan yang digunakan dapat diperoleh di sekitar Kota Bintuni. Oleh sebab itu digester sederhana sangat tepat untuk diintroduksikan kepada peternak sapi potong di Kabupaten Teluk Bintuni.

\subsection{Uji Coba Pembakaran Biogas}

Setelah 3 minggu pengisian a donan kotoran temak ke dala $m$ biodigester maka terjadi fermentasi secara anarob oleh bakteri sehingga terbentuk gas yang diindikasikan dengan plastik penampung gas menggelembung. Pada saat kompor biogas disulut dengan pemantik api maka terlihat nyala a piberwarna biru. Nyala a pi merupakan salah satu indikator berhasil atau tidaknya proses fermentasi yang menghasilkan biogas. Apabila api dapat menyala maka hal ini menunjukkan bahwa hasil pembentukan bioga s memiliki kandungan gas metana diatas 40\%. Menurut (Ihsan et al., 2013) jika gas yang dihasilkan dari proses anaerobik dapat terbakar kemungkinan mengandung $45 \%$ gas metana. Pada umumnya bila ga s metana dibakar akan menghasilkan warna biru dan nyala a pi tidak mudah padam.

Pada uji coba tersebut kompor yang berbahan bakar bioga s digunakan untuk memasak air hingga mendidih. Dengan demikian peserta kegiatan dapat melihat langsung hasil a khir dari kegiatan pelatihan ini yaitu tersedia nya sumber energi alternatif untuk memenuhi kebutuhan rumah tangga. Suhendra (2008) melaporkan bahwa energi yang terkandung dalam $1 \mathrm{~m}^{3}$ biogas sebesar 2.000-4.000 kkal atau dapat memenuhi kebutuhan memasak bagi satu keluarga (4-5 orang) selama 3 jam. Apabila peternak dapat mengoperasikan perangkat biodigester ini secara kontinyu, maka para peternak memperoleh keuntun gan secara ekonomi yaitu reduksibiaya untuk pembelian minyak tanah. Menurut Wahyuni (2013), nilai kalori dari $1 \mathrm{~m}^{3}$ biogas setara dengan 0,6-0,8 liter minyak tanah.

Energi alternatif yang bersumber dari biogas ini selanjutnya dimanfaatkan oleh peternakan sebagai pengganti bahan bakar minyak untuk menyalakan kompor di dapur mereka. Setelah kegiatan ini, diha rapkan peternak sapipotong yang memihara temak 3-5 ekor dapat mengaplikasikan teknologi digester sederhana di rumah masing-masing, tidak hanya di Distrik Manimeri, namun dikembangkan diDistrik la in diKabupaten Teluk Bintuni. Pemerintah daerah melalui instansi terkait dan pihak swata perlu juga memfasilitasi pengembangan teknologi biogas di Kabupaten Teluk Bintuni dalam ra ngka mengurangi ketergantungan pada bahan bakar minyak dan gas elpiji.

Selain energi biogas yang dihasilkan dari proses fermentasi secara anaerob di dalam digester, maka diha silkan pula limbah bio-slurry dalam bentuk padat dan cair yang dapat digunakan sebagai pupuk tanaman. Menurut Devarenjan et al. (2019), slurry terdiri atas 
$94 \%$ air, $4,5 \%$ bahan padat dan $2,5 \%$ bahan a norganik. Slurry mengandung makro nutrien yaitu N, P dan K, dan mikro nutrien seperti $\mathrm{Ca}, \mathrm{Mg}$, Fe, $\mathrm{Mn}$ dan $\mathrm{Zn}$.

\section{KESIMPULAN}

Peternak sapi potong yang mengikuti sosialisasi dan pelatihan teknologi biogas menyatakan kegiatan ini sangat manfaat dalam ra ngka penyediaan sumber energi alternatif yang ra mah lingkungan. Disa mping itu dari fermentasi di da la m biodigester peternak memperoleh pupuk organik padat dan cair yang siap dipakai. Biodigester model sederhana dapat dia plikasikan pada peternak sa pi di Kabupaten Teluk Bintuni dengan skala kepemilikan ternak 3-5 ekor. Da lam jangka panjang, pemerintah dan pihak swasta dapat memberikan subsidi digester biogas dalam rangka pengembangan teknologi biogas sehingga dapat mengurangi ketergantungan ma syarakat pada bahan bakar minyak dan ga s elpiji.

\section{UCAPAN TERIMA KASIH}

Tim Pelaksana mengucapkan terima kasih kepadaDinas Pertanian Kabupaten Teluk Bintuni yang telah menyediakan dana kegiatan ini sesuai dengan Surat Perjanjian Kontrak No. 521.03.011/VII/2019.

\section{DAFTAR PUSKAKA}

Al Seadi, T., Rutz, D., Janssen, R. and Drosg, B. (2013). Biomass resources for biogas production. In. Wellinger A. (Eds) The Biogas Handbook. Woodhead Publishing. Oxford Cambridge Philadelphia New Delhi.

BPS Kabupaten Teluk Bintuni. (2017). Kabupaten Teluk Bintuni Dalam Angka. Badan Pusat Statistik Kabupaten Teluk Bintuni.

Devarenjan, J., Herbert G. M. J, and Amutha, D. (2019). Utilization of bioslurry from biogas plant as fertilizer. International Journal of Recent Technology and Engineering 8(4): 122 10-12213.

Ihsan, A., Syaiful B., dan Musafira. (2013). Produksi biogas menggunakan cairan isi rumen sapi dengan limbah cair tempe. Jurnal of Natural Science 2(2): 27-33.

Herriya nti, A. P. (2015). Pengelolaan limbah ternaksapi menjadi biogas. Majalah Ilmiah Pawiyatan 22 (1): 39-48.

Karno, Karno, dan Hery K. (2013). Panduan Praktis: Membuat Biogas Itu Mudah dan Mudah. Penerbit Forum Ilmiah Kesehatan (Forikes), Jakarta.

Suhendra, F. (2008). The Usage of Biogas Technology to Reduce Livestock Pollutant in Bali on Clean Development Mechanism. Muly a Tiara Nusa

Wahyuni, S. (2013). Panduan Praktis Biogas. Jakarta: Penebar Swadaya. 